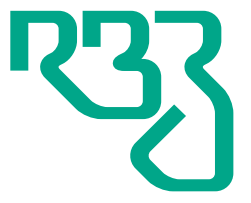

Revista

Brasileira de

Zootecnia

Brazilian Journal of Animal Science

ISSN 1806-9290

www.rbz.org.br

\title{
Effects of dietary supplementation of kefir on body measurements, weight of visceral organs, and gut morphology in geese
}

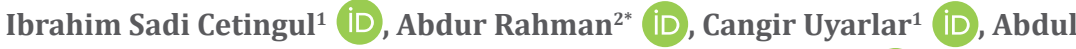 \\ Burhanettin Akkaya $^{1}$, Eyup Eren Gultepe ${ }^{1}$ iD , Aykut Ulucan ${ }^{3}$ (iD, Ismail \\ Bayram $^{1}$ iD \\ ${ }^{1}$ Afyon Kocatepe University, Department of Animal Nutrition and Nutritional Disorders, \\ Afyonkarahisar, Turkey. \\ ${ }^{2}$ University of Veterinary and Animal Sciences, Department of Animal Nutrition, Lahore \\ (Jhang Campus), Pakistan. \\ ${ }^{3}$ Bingol University, Department of Medical Services and Techniques, Bingol, Turkey.
}

*Corresponding author:

abdurrehman@uvas.edu.pk

Received: March 18, 2019

Accepted: July 14, 2019

How to cite: Cetingul, I. S.; Rahman, A.;

Uyarlar, C.; Akkaya, A. B.; Gultepe, E. E.;

Ulucan, A. and Bayram, I. 2019. Effects of

dietary supplementation of kefir on body

measurements, weight of visceral organs, and

gut morphology in geese. Revista Brasileira de Zootecnia 48:e20180306.

https://doi.org/10.1590/rbz4820180306

Copyright: This is an open access article distributed under the terms of the

Creative Commons Attribution License

(http://creativecommons.org/licenses/by/4.0/),

which permits unrestricted use, distribution,

and reproduction in any medium, provided the

original work is properly cited.

\begin{abstract}
This study was designed to evaluate the effects of adding kefir on body measurements, giblet weight, and gut morphological patterns of geese through drinking water. A total of 54 birds were divided into three groups, each comprising 18 birds, and each group was further divided into three subgroups containing six birds each. One group served as the control group, while the other two groups were given kefirtreated drinking water at the ratios of 2.5 and $7.5 \%$, respectively. No significant effects of kefir supplementation on body measurements, spleen weight, bursa weight, and gut morphology were observed. It is concluded that kefir may be used in poultry feed with an inclusion rate of $7.5 \%$ without imposing any adverse effect on the measurements of body structures, weights of visceral organs, and gut morphology.
\end{abstract}

Keywords: crypt depth, geese, natural alternatives, probiotic, villus length

\section{Introduction}

The recent developments in the poultry sector have led to several innovations in profitable farming and production of safer foods for consumers. At the start of the 21 st century, it was earnestly observed that administration of low-level doses of antibiotics in poultry feed for growth promotion resulted in chronic drug resistance leading to serious human health concerns. Ultimately in 2003, the use of antibiotics was completely banned in Europe, which urged the need to explore alternative feed additives that could fill the gap created by the ban of antibiotics and replace them in poultry feeds, while maintaining the same production levels.

A variety of feed additives are being used in the poultry sector, including phytogenic additives, enzymes, prebiotics, probiotics, and organic acids as alternatives to antibiotics (Karademir and Karademir, 2003). Probiotics are complex mixtures of microbes and are claimed to promote growth rate and health of animals by preventing the attachment of coliform bacteria, minimizing or inhibiting the growth of pathogenic bacteria, changing the absorption of nutrients from the intestine and modifying the balance of the microbes in the gut. They also seem effective in preventing or treating digestive disorders caused by stress (Reinhardt, 2015).

Kefir is one of the few products among probiotics that are being used in the poultry industry. It contains lactic acid bacteria and yeast (Marshall and Cole, 1985), $900 \mathrm{~g} \mathrm{~kg}^{-1}$ moisture, about $100 \mathrm{~g} \mathrm{~kg}^{-1}$ dry 
matter, $30 \mathrm{~g} \mathrm{~kg}^{-1}$ fat, $70 \mathrm{~g} \mathrm{~kg}^{-1}$ ash, $300 \mathrm{~g} \mathrm{~kg}^{-1}$ protein content, and $550 \mathrm{~g} \mathrm{~kg}^{-1}$ nitrogen free extracts (Sekkal-Taleb, 2016). Kefir is made from the fermentation of milk or kefir grains by using a starter culture (Liu and Moon, 1983). It contains alcohol with a slightly acidic $\mathrm{pH}$ and is milky in appearance. It is well known that probiotics have potential effects on the growth performance of poultry including body weight gain and feed conversion ratio (Huang et al., 2004) and improve some other parameters such as meat and carcass quality (Pelicano et al., 2003; Kalavathy et al., 2006).

Kefir has been studied in many other poultry species (Kandir and Yardimci, 2015), but there is still a lack of sufficient literature to explore the effects of kefir as a probiotic in geese. Considering the aforementioned, this study was designed to investigate the effects of supplementation of kefir in drinking water on the body measurements, giblet weight, and intestinal morphology of geese.

\section{Material and Methods}

This study was conducted on a commercial farm in the province of Afyonkarahisar in Turkey (3845'24.7896" $\mathrm{N}$ latitude, $30^{\circ} 32$ '19.3344" E longitude, and $826 \mathrm{~m}$ altitude).

A total of 54 goslings, 21 days old each, were obtained from a hatchery and reared on floor pens with wood dust as litter. All managerial practices were performed as recommended for geese production. The temperature was adjusted at 25 and $20^{\circ} \mathrm{C}$ for the $3 \mathrm{rd}$ and 4 th weeks, respectively, and $20^{\circ} \mathrm{C}$ for the remaining period. A 24-h lighting schedule was followed during the experiment.

Kefir was prepared from kefir grains that were procured from the Department of Food Hygiene and Technology, Faculty of Veterinary Medicine at Afyon Kocatepe University. It was manufactured by mixing $5 \%$ of active kefir grains with $3 \%$ of UHT cow milk and kept at $22{ }^{\circ} \mathrm{C}$ for $20 \mathrm{~h}$ for incubation (Marshall and Cole, 1985).

The birds were divided into three groups containing 18 birds in each, and each group was further subdivided into three subgroups comprising six birds each. One group was offered normal drinking water without any supplementation, as the control group, while the other two groups received 2.5 and 7.5\% kefir in drinking water, respectively, by using individual drinker types for each replicate.

During 3-6 weeks of age, the goslings were fed a starter diet containing $220 \mathrm{~g} \mathrm{~kg}^{-1}$ crude protein (CP), $2,900 \mathrm{kcal} \mathrm{kg}^{-1}$ metabolizable energy (ME), and then, grower diet was provided during 7-12 weeks of age with $150 \mathrm{~g} \mathrm{~kg}^{-1} \mathrm{CP}$ and 2,900 kcal kg-1 ME (Table 1). The experiment lasted for 63 days (nine weeks). At the end of the experiment, six birds from each group (from amongst 18) were slaughtered. Body length, neck length, wing length, and chest circumference values of the birds were recorded. After slaughtering, spleens and bursae were collected and weighed. For sample collection from the intestines, the whole intestinal tract was taken out. The tissues were prepared from the intestines for histopathological examination by the method described by Awad et al. (2011). The samples were collected from different parts of the intestines to measure the villus height, crypt depth, and tunica muscularis thickness. The gut samples were then preserved in a $10 \%$ buffered formalin solution for $48 \mathrm{~h}$.

A 1.5-2-cm segment sample from the duodenum was taken $10 \mathrm{~cm}$ beyond the gizzard-duodenal junction, $5 \mathrm{~cm}$ proximal to the Meckel's diverticulum for jejunum and $5 \mathrm{~cm}$ proximal to the ileocecal junction for ileum. From the preserved samples, a proper section was cut and embedded in paraffin for routine histological examinations. After embedding, 4- $\mu \mathrm{m}$ sections were cut from each block by a microtome, mounted on a slide, and stained by hematoxylin \& eosin (H\&E) (Sakamoto et al., 2000; Solis de los Santos et al., 2005). The slides that were prepared were then examined in a light microscope equipped with a digital camera (Olympus CX41 attached Kameram R Digital Image Analyze System) from 10 different places for each parameter in each slide. The villus height was measured from the top of the villus up to the lamina propria (Sakamoto et al., 2000). The crypt depth was analyzed and noted between the crypt and villus, while the mucosa (Muscularis thickness) was measured from the top of the villus to the base of the muscularis mucosa (Aptekmann et al., 2001).

R. Bras. Zootec., 48:e20180306, 2019 
Table 1 - Ingredient and chemical composition of diet given to different groups of geese at 3-12 weeks of age

\begin{tabular}{lcc}
\hline Item & Starter diet $\left(\mathrm{g} \mathrm{kg}^{-1}\right)$ & Grower diet $\left(\mathrm{g} \mathrm{kg}^{-1}\right)$ \\
\hline Ingredient & & 480.0 \\
Corn & 480.0 & 100.0 \\
Wheat & 100.0 & 100.1 \\
Wheat bran & 0 & 70.0 \\
Maize bran & 0 & 37.5 \\
Sorghum & 0 & 10.0 \\
Sunflower oil & 0 & 0 \\
Full fat soybean & 100.0 & 150.0 \\
Sunflower meal & 200.0 & 0 \\
Soybean meal & 70.0 & 20.7 \\
Molasses & 20.7 & 15.3 \\
Limestone & 15.3 & 10.0 \\
Dicalcium phosphate (DCP) & 7.6 & 2.5 \\
Salt & 2.5 & 3.5 \\
Vitamin-mineral premix & \\
Methionine & 3.5 & 0.4 \\
Nutrient composition & 0.4 & 890 \\
Dry matter (g kg-1) & & 150 \\
Crude protein (g kg-1) & 890 & 2900 \\
Metabolizable energy $\left(\mathrm{kcal} \mathrm{kg-1}^{-1}\right)$ & 220 & \\
\hline
\end{tabular}

${ }^{1}$ Provided per kg of diet: vitamin A, 12,000,000 IU; Vitamin D3, 3,000,000 IU; vitamin E, 35,000 IU; vitamin K3, 3,500 IU; vitamin B1, 2,750 IU; vitamin B2, 5,500 IU; vitamin B3, 30,000 IU; Ca-D panthotenate, 10,000 IU; vitamin B6, 4,000 IU; vitamin B12, 15 IU; folic acid, 1,000 IU; D-biotin, $50 \mathrm{IU}$; choline chloride, 150,000 IU; manganese, 80,000 mg; iron, 60,000 mg; zinc, 60,000 mg; copper, 5,000 mg; iodine, 2,000 mg; cobalt, $500 \mathrm{mg}$; selenium, $150 \mathrm{mg}$; antioxidant, 15,000 mg.

The model assumptions of normality and homogeneity of variance were examined by Shapiro-Wilk and Levene's tests, respectively. The statistical analysis was performed by SPSS-10. An ANOVA was used for group comparisons, followed by Duncan's multiple range test for post-hoc analysis. The statistical model used to test the effects of treatment on the variables was:

$$
\mathrm{Y}_{\mathrm{ij}}=\mu+\alpha_{\mathrm{i}}+\mathrm{e}_{\mathrm{ij}},
$$

in which $Y_{i j}=$ the response variable, $\mu=$ general mean, $\alpha_{i}=$ the effect of dietary treatments (DF $=2$ ), and $\mathrm{e}_{\mathrm{ij}}=$ the random error. The significance level was considered as $\mathrm{P}<0.05$.

\section{Results}

The results of the study indicated that there was no significant effect $(\mathrm{P}>0.05)$ of kefir supplementation on body, neck, and wing length or chest circumference (Table 2). Similarly, no effect was observed in the cases of spleen and bursa weights in all supplemented groups in comparison with the control group (Table 3). The differences in muscular thickness, crypt depth, villus height, and villus height:crypt depth ratio were recorded as non-significant in all groups in comparison with the control group (Tables 4 and 5).

Table 2 - Body measurements of geese at 3-12 weeks (63 days) of age offered different kefir treatments

\begin{tabular}{|c|c|c|c|c|c|c|c|}
\hline \multirow{2}{*}{ Body measurement $(\mathrm{cm})$} & \multicolumn{2}{|c|}{$0 \%$ kefir } & \multicolumn{2}{|c|}{$2.5 \%$ kefir } & \multicolumn{2}{|c|}{$7.5 \%$ kefir } & \multirow{2}{*}{ P-value } \\
\hline & Mean & SEM & Mean & SEM & Mean & SEM & \\
\hline Body length & 33.00 & 0.37 & 32.20 & 1.20 & 33.00 & 0.68 & 0.69 \\
\hline Neck length & 20.50 & 0.50 & 20.20 & 1.11 & 22.17 & 0.31 & 0.13 \\
\hline Wing length & 45.67 & 0.95 & 45.20 & 1.46 & 46.00 & 1.06 & 0.88 \\
\hline Chest circumference & 36.00 & 0.68 & 36.40 & 0.81 & 35.83 & 0.79 & 0.87 \\
\hline
\end{tabular}

SEM - standard error of the mean. 
Table 3 - Weight of visceral organs of geese at 3-12 weeks (63 days) of age offered different kefir treatments

\begin{tabular}{|c|c|c|c|c|c|c|c|}
\hline \multirow{2}{*}{ Visceral measurement (g) } & \multicolumn{2}{|c|}{$0 \%$ kefir } & \multicolumn{2}{|c|}{$2.5 \%$ kefir } & \multicolumn{2}{|c|}{$7.5 \%$ kefir } & \multirow{2}{*}{ P-value } \\
\hline & Mean & SEM & Mean & SEM & Mean & SEM & \\
\hline Spleen & 1.83 & 0.07 & 1.98 & 0.14 & 1.92 & 0.29 & 0.86 \\
\hline Bursa & 1.93 & 0.20 & 1.93 & 0.13 & 2.45 & 0.34 & 0.31 \\
\hline
\end{tabular}

SEM - standard error of the mean.

Table 4 - Villus height, crypt depth, and tunica muscularis thickness of geese intestine at 3-12 weeks (63 days) of age offered different kefir treatments

\begin{tabular}{|c|c|c|c|c|c|c|c|}
\hline \multirow{2}{*}{ Muscular layer thickness $(\mu \mathrm{m})$} & \multicolumn{2}{|c|}{$0 \%$ kefir } & \multicolumn{2}{|c|}{$2.5 \%$ kefir } & \multicolumn{2}{|c|}{$7.5 \%$ kefir } & \multirow{2}{*}{ P-value } \\
\hline & Mean & SEM & Mean & SEM & Mean & SEM & \\
\hline Duodenum & 184.13 & 8.95 & 172.80 & 20.75 & 187.57 & 11.60 & 0.63 \\
\hline Ileum & 187.77 & 29.85 & 204.39 & 8.37 & 212.09 & 20.21 & 0.52 \\
\hline Cecum & 181.68 & 8.33 & 198.43 & 6.40 & 198.98 & 10.05 & 0.29 \\
\hline Colon & 373.11 & 28.45 & 388.83 & 28.84 & 310.21 & 26.87 & 0.15 \\
\hline \multicolumn{8}{|l|}{ Crypt depth $(\mu \mathrm{m})$} \\
\hline Duodenum & 86.88 & 3.75 & 98.93 & 10.49 & 93.89 & 2.85 & 0.43 \\
\hline Ileum & 81.56 & 2.39 & 89.96 & 5.85 & 81.24 & 4.24 & 0.37 \\
\hline Cecum & 66.79 & 6.11 & 63.69 & 7.16 & 59.17 & 4.10 & 0.65 \\
\hline Colon & 75.26 & 4.33 & 80.96 & 1.93 & 80.50 & 2.59 & 0.34 \\
\hline \multicolumn{8}{|l|}{ Villus height $(\mu \mathrm{m})$} \\
\hline Duodenum & 394.83 & 46.11 & 491.00 & 18.28 & 420.64 & 6.71 & 0.16 \\
\hline Ileum & 460.35 & 39.32 & 434.42 & 10.10 & 364.65 & 40.17 & 0.16 \\
\hline Cecum & 263.49 & 47.39 & 192.71 & 14.37 & 186.36 & 9.06 & 0.19 \\
\hline Colon & 417.91 & 34.91 & 424.02 & 16.02 & 416.69 & 16.38 & 0.94 \\
\hline
\end{tabular}

SEM - standard error of the mean.

Table 5 - Relative villus height and crypt depth of the intestine of geese at 3-12 weeks (63 days) of age offered different kefir treatments

\begin{tabular}{|c|c|c|c|c|c|c|c|}
\hline \multirow{2}{*}{ Villus height:crypt depth ratio } & \multicolumn{2}{|c|}{$0 \%$ kefir } & \multicolumn{2}{|c|}{$2.5 \%$ kefir } & \multicolumn{2}{|c|}{$7.5 \%$ kefir } & \multirow{2}{*}{ P-value } \\
\hline & Mean & SEM & Mean & SEM & Mean & SEM & \\
\hline Duodenum & 4.64 & 0.62 & 5.20 & 0.60 & 4.50 & 0.16 & 0.60 \\
\hline Ileum & 5.73 & 0.67 & 4.90 & 0.32 & 4.50 & 0.52 & 0.28 \\
\hline Cecum & 3.80 & 0.42 & 3.10 & 0.42 & 3.20 & 0.31 & 0.39 \\
\hline Colon & 5.60 & 0.57 & 5.20 & 0.27 & 5.20 & 0.30 & 0.71 \\
\hline
\end{tabular}

SEM - standard error of the mean.

\section{Discussion}

Kefir belongs to a probiotic group that may exert positive and healthy effects on the host when ingested, by changing the microbial environment of the gut (Fuller, 1989). Probiotics may produce beneficial effects as they contain microorganisms such as lactic acid-producing bacteria lactobacilli, streptococcus, and bifidobacterial and may also induce some adverse effects because of the enterobacteria, clostridium, and enterococcus species. It is also known that probiotics inflict predominantly good effects on intestinal microbiota in enhancing its population and making it able enough to protect the intestines from pathogens, while maintaining the microbial population balance in the gut (Urdaneta et al., 2007; Yaman et al., 2006).

This study revealed that supplementation of kefir at the ratio of 2.5 and $7.5 \%$ in drinking water did not show any significance effect on body measurements in comparison with the control group. Kandir and 
Yardimci (2015) also observed no significant effect of kefir supplementation with respect to head and foot size at the same dose levels in ducks. Likewise, it is evident that there is no well-known relationship between supplementation of probiotics and mineral absorption or bone measurements (Stavric and Kornegay, 1995; Jin et al., 1997; Simmering and Blaut, 2001; Patterson and Burkholder, 2003).

Although probiotics have been investigated extensively in poultry to explore their effects on various parameters such as performance and immune parameters and proven to be effective in many cases by improving performance, maintaining digestive health, and reducing dependence on antibiotics (Reinhardt, 2015), kefir has not been investigated much to record its effect on body measurements. Another study observed that probiotic (yeast) supplementation reduced tibial dyschondroplasia and improved bone strength (Plavnik and Scott, 1980), which demonstrated that probiotics may have beneficial impacts on bone parameters that might be due to the positive correlation between usage of probiotics and Ca:P retention (Nahashon et al., 1994).

The spleen and bursa weights were also not affected significantly by kefir supplementation on any level. Some other researchers also reported no significant increase in giblet weight in geese fed a kefirsupplemented diet (Sahin and Yardimci, 2009). Likewise, Karademir and Unal (2009) observed no significant difference in giblet organ weight in broilers given a diet with kefir. These results indicate that kefir may improve carcass hygiene by influencing the microbial balance in intestine (Yaman et al., 2006) but has no effect on body measurements. Similarly, Yenice et al. (2014) reported no significant increase in heart weight, but contrary to our results, they showed an increase in live and gizzard weight in kefir-supplemented groups. In our study, there was no significant increase or decrease in spleen and bursa weights, which might be related to feed intake, which remained unchanged in the kefir-treated groups.

Limited data are available regarding the effects of kefir supplementation on intestinal morphology. A study conducted by Urdaneta et al. (2007) demonstrated that kefir supplementation had a pronounced effect on intestinal enzyme activity and increased absorption of nutrients with no change in the morphologic structure in jejunum. These findings were similar to our results, indicating that supplementing kefir in drinking water has no effects on villus height, crypt depth, muscularis thickness, or on villus height:crypt depth ratio. Although kefir ingestion resulted in improvement of the population of beneficial lactobacillus microflora and decreasing of the population of aerobic microflora to maintain good health of the gut (Yaman et al., 2006), no effect was found in the gut in terms of morphology.

Based on the results of this study, it may be stated that kefir has no adverse effects if supplemented for geese via drinking water. Likewise, some studies reported that the use of kefir is beneficial in enhancing performance, immunity, suggested gut microbiota, and blood parameters (Cavazzoni et al., 1998; Abdulrahim et al., 1999; Santoso et al., 2001; Kalavathy et al., 2006; Arslan and Saatci, 2004; Karademir and Unal, 2009; Cenesiz et al., 2008; Salarmoini and Fooladi, 2011; Cho et al., 2013; Thoreux and Schmucker, 2001; Marquina et al., 2002; Vinderola et al., 2006; Urdaneta et al., 2007).

\section{Conclusions}

The use of kefir in drinking water at the ratios of 2.5 and $7.5 \%$ show no significant effect on the weights of visceral organs, body measurements, and gut morphology. It may be recommended to use kefir in geese up to $7.5 \%$ without causing adverse effects on body structure and gut morphology of geese.

\section{Conflict of Interest}

The authors declare no conflict of interest.

\section{Author Contributions}

Conceptualization: I.S. Cetingul. Data curation: E.E. Gultepe. Formal analysis: A. Ulucan. Investigation: A.B. Akkaya. Methodology: E.E. Gultepe and A. Ulucan. Project administration: I. Bayram. Resources: 
C. Uyarlar and A.B. Akkaya. Supervision: I. Bayram. Visualization: I. Bayram. Writing-original draft: A. Rahman. Writing-review \& editing: A. Rahman and C. Uyarlar.

\section{References}

Abdulrahim, S. M.; Haddadin, M. S. Y.; Odetallah, N. H. M. and Robinson, R. K. 1999. Effect of Lactobasillus acidophilus and zinc bacitracin as dietary additives for broiler chickens. British Poultry Science 40:91-94. https://doi. org/10.1080/00071669987890

Aptekmann, K. P.; Baraldi Artoni, S. M.; Stefanini, M. A. and Orsi, M. A. 2001. Morphometric analysis of the intestine of domestic quails (Coturnix coturnix japonica) treated with different levels of dietary calcium. Anatomia, Histologia, Embryologia 30:277-280. https://doi.org/10.1046/j.1439-0264.2001.00331.x

Arslan, C. and Saatci, M. 2004. Effects of probiotic administration either as feed additive or by drinking water on performance and blood parameters of Japanese quail. Archiv fur Geflugelkunde 68:160-163.

Awad, W. A.; Ghareeb, K. and Böhm, J. 2011. Evaluation of the chicory inulin efficacy on ameliorating the intestinal morphology and modulating the intestinal electrophysiological properties in broiler chickens. Journal of Animal Physiology and Animal Nutrition 95:65-72. https://doi.org/10.1111/j.1439-0396.2010.00999.x

Cavazzoni, V.; Adami, A. and Castrovilli, C. 1998. Performance of broiler chickens supplemented with Basillus coagulans as probiotic. British Poultry Science 39:526-529. https://doi.org/10.1080/00071669888719

Cenesiz, S.; Yaman, H.; Ozcan, A.; Kart, A. and Karademir, G. 2008. Effects of kefir as a probiotic on serum cholesterol, total lipid, aspartate amino transferase, and alanine aminotransferase activities in broiler chicks. Medycyna Weterynaryjna 64:168-170.

Cho, J. H.; Zhang, Z. F. and Kim, I. H. 2013. Effects of single or combined dietary supplementation of $\beta$-glucan and kefir on growth performance, blood characteristics and meat quality in broilers. British Poultry Science 54:216-221. https://doi. org/10.1080/00071668.2013.777691

Fuller, R. 1989. Probiotics in man and animals. Journal of Applied Bacteriology 66:365-378.

Huang, M. K.; Choi, Y. J.; Houde, R.; Lee, J. W.; Lee, B. and Zhao, X. 2004. Effects of Lactobacilli and an acidophilic fungus on the production performance and immune responses in broiler chickens. Poultry Science 83:788-795. https://doi.org/10.1093/ps/83.5.788

Jin, L. Z.; Ho, Y. W.; Abdullah, N. and Jalaludin, S. 1997. Probiotics in poultry: modes of action. World's Poultry Science Journal 53:351-368. https://doi.org/10.1079/WPS19970028

Kalavathy, R.; Abdullah, N.; Jalaludin, S.; Wong, M. C. V. L. and Ho, Y. W. 2006. Effects of Lactobacillus feed supplementation on cholesterol, fat content and fatty acid composition of the liver, muscle and carcass of broiler chickens. Animal Research 55:77-82. https://doi.org/10.1051/animres:2005043

Kandir, E. H. and Yardimci, M. 2015. Effects of kefir on growth performance and carcass characteristics in Pekin ducks (Anas platyrhynchos domestica). Journal of Animal Research 5:207-212. https://doi.org/10.5958/2277-940X.2015.00035.2

Karademir, G. and Karademir, B. 2003. Biotechnologic products using as feed supplement. Lalahan Hayvancılık Araştırma Enstitüsü Dergisi 43:61-74.

Karademir, G. and Unal, Y. 2009. The use of kefir as probiotic in broiler. Lalahan Hayvancllık Araștırma Enstitüsü Dergisi 49:47-54.

Liu, J. A. P. and Moon, N. J. 1983. Kefir - a new fermented milk product. Cultured Dairy Products Journal 18:11-12.

Marquina, D.; Santos, A.; Corpas, I.; Muñoz, J.; Zazo, J. and Peinado, J. M. 2002. Dietary influence of kefir on microbial activities in the mouse bowel. Letters in Applied Microbiology 35:136-140. https://doi.org/10.1046/j.1472-765X.2002.01155.x

Marshall, V. M. and Cole, W. M. 1985. Methods for making kefir and fermented milks based on kefir. Journal of Dairy Research 52:451-456. https://doi.org/10.1017/S0022029900024353

Nahashon, S. N.; Nakaue, H. S. and Mirosh, L. W. 1994. Phytase activity, phosphorous and calcium retention, and performance of single comb white leghorn layers fed diets containing two levels of available phosphorous and supplemented with direct-fed microbials. Poultry Science 73:1552-1562. https://doi.org/10.3382/ps.0731552

Patterson, J. A. and Burkholder, K. M. 2003. Application of prebiotics and probiotics in poultry production. Poultry Science 82:627-631. https://doi.org/10.1093/ps/82.4.627

Pelicano, E. R. L.; Souza, P. A.; Souza, H. B. A.; Oba, A.; Boiago, M. M.; Zeola, N. M. B. L.; Scatolini, A. M.; Bertanha, V. A. and Lima T. M. A. 2003. Carcass and cut yields and meat qualitative traits of broilers fed diets containing probiotics and prebiotics. Brazilian Journal of Poultry Science 7:169-175. https://doi.org/10.1590/S1516-635X2005000300006

Plavnik, I. and Scott, M. L. 1980. Effects of additional vitamins, minerals or brewer's yeast upon leg weaknesses in broiler chickens. Poultry Science 59:459-464. https://doi.org/10.3382/ps.0590459

Reinhardt, C. D. 2015. Probiotics. Available at: <http://www.merckvetmanual.com/mvm/pharmacology/growth_ promotants_and_production_enhancers/probiotics.html>. Accessed on: June 25, 2019.

R. Bras. Zootec., 48:e20180306, 2019 
Sahin, E. H. and Yardimci, M. 2009. Effect of kefir as a probiotic on growth performance and carcass characteristics in geese (Anser anser). Journal of Animal and Veterinary Advances 8:562-567.

Sakamoto, K.; Hirose, H.; Onizuka, A.; Hayashi, M.; Futamura, N.; Kawamura, Y. and Ezaki, T. 2000. Quantitative study of changes in intestinal morphology and mucus gel on total parenteral nutrition in rats. Journal of Surgical Research 94:99-106. https://doi.org/10.1006/jsre.2000.5937

Salarmoini, M. and Fooladi, M. H. 2011. Efficacy of Lactobacillus acidophilus as probiotic to improve broiler chicks performance. Journal of Agricultural Science and Technology 13:165-172.

Santoso, U.; Tanaka, K.; Ohtani, S. and Sakaida, M. 2001. Effect of fermented product from Bacillus subtilis on feed conversion efficiency, lipid accumulation and ammonia production in broiler chicks. Asian-Australasian Journal of Animal Sciences 14:333-337. https://doi.org/10.5713/ajas.2001.333

Sekkal-Taleb, N. 2016. Chemical and microbiological composition of Kefir and its natural benefits. Mediterranean Journal of Biosciences 1:174-183.

Simmering, R. and Blaut, M. 2001. Pro-and prebiotics - the tasty guardian angels? Applied Microbiology and Biotechnology 55:19-28. https://doi.org/10.1007/s002530000512

Solis de los Santos, F.; Tellez, G.; Farnell, M. B.; Balog, J. M.; Anthony, N. B.; Pavlidis, H. O. and Donoghue, A. M. 2005. Hypobaric hypoxia in ascites resistant and susceptible broiler genetic lines influences gut morphology. Poultry Science 84:1495-1498. https://doi.org/10.1093/ps/84.9.1495

Stavric, S. and Kornegay, E. T. 1995. Microbial probiotics for pigs and poultry. p.205-231. In: Biotechnology in animal feeds and animal feeding. Wallace, R. J. and Chesson, A., eds. VCH, New York, NY. https://doi.org/10.1002/9783527615353.ch10

Thoreux, K. and Schmucker, D. L. 2001. Kefir milk enhances intestinal immunity in young but not old rats. The Journal of Nutrition 131:807-812. https://doi.org/10.1093/jn/131.3.807

Urdaneta, E.; Barrenetxe, J.; Aranguren, P.; Irigoyen, A.; Marzo, F. and Ibanez, F. C. 2007. Intestinal beneficial effects of kefir-supplemented diet in rats. Nutrition Research 27:653-658. https://doi.org/10.1016/j.nutres.2007.08.002

Vinderola, G.; Perdigon, G.; Duarte, J.; Thangavel, D.; Farnworth, E. and Matar, C. 2006. Effects of kefir fractions on innate immunity. Immunobiology 211:149-156. https://doi.org/10.1016/j.imbio.2005.08.005

Yaman, H.; Ulukanl, Z.; Elmali, M. and Unal, Y. 2006. The effect of a fermented probiotic, the kefir, on intestinal flora of poultry domesticated geese (Anser anser). Revue de Medecine Veterinaire 157:379-386.

Yenice, G.; Celebi, D.; Yoruk, M. A.; Ucar, O.; Saglam, Y. S.; Tunc, M. A. and Altun, S. 2014. Effect of kefir upon the performance, intestinal microflora and histopathology of certain organs in laying hens. Kafkas Universitesi Veteriner Fakultesi Dergisi 20:363-370. https://doi.org/10.9775/kvfd.2013.10173 